\title{
IMPLEMENTASI KEBIJAKAN DESENTRALISASI FISKAL DI PROVINSI SUMATERA SELATAN
}

\author{
Rosmery Elsye \\ Fakultas Manajemen Pemerintahan Institut Ilmu Pemerintahan Dalam Negeri \\ E-mail: rosmerye8@gmail.com
}

\begin{abstract}
ABSTRAK Permasalahan dalam implementasi kebijakan desentralisasi fiskal di Provinsi Sumatera Selatan adalah belum optimal dalam meningkatakan pendapatan Daerah di Provinsi Sumatera Selatan. Oleh sebab itu tujuan penelitian ini untuk memberikan kontribusi dalam mengembangkan konsep baru yaitu kebijakan publik dalam melakukan implementasi kebijakan desentralisasi fiskal. Metode yang digunakan dalam penelitian ini adalah penelitian kualitatif, dengan desain eksploratif. Teknik pengumpulan data melalui wawancara, opservasi dan dokumentasi. Penelitian ini memfokuskan pada implementasi kebijakan desentralisasi fiskal, dengan menggunakan model implementasi kebijakan menurut Edward III akan diketahui faktor-faktor yang berperan dalam implementasi kebijakan desentralisasi fiskal di Provinsi Sumatera Selatan. Hasil penelitian menunjukkan bahwa implementasi kebijakan desentralisasi fiskal di Provinsi Sumatera Selatan belum berjalan optimal, dalam pengelolaan APBD dalam mendukung budgetair, terutama untuk mengalokasikan pengeluaran Pembangunan Pememerintah Daerah Provinsi Sumatera Selatan. Untuk memperbaiki implementasi kebijakan desentralisasi fiskal Pemerintah Provinsi Sumatera Selatan dapat dicapai melalui peningkatan kemampuan pemahaman dan sikap konsisten para pelaku pelaksana kebijakan, komitmen dan tanggungjawab dari pemerintah daerah selaku organizational level untuk mengalokasikan semua anggaran, penetapan kejelasan kewenangan, metode dan prosedur kerja, dan kejelasan standar yang dijadikan sebagai pedoman dalam upaya implementasi kebijakan tersebut.
\end{abstract}

katakunci : Implementasi, Kebijakan, Desentralisasi, Fiskal, Sumatra Selatan

\section{THE POLICY IMPLEMENTATION OF FISCAL DECENTRALIZATION IN SOUTH SUMATRA PROVINCE}

\begin{abstract}
Problems in the implementation of fiscal decentralization policy in the province of South Sumatra is not optimal in income increase the area of South Sumatra Province. Therefore the purpose of this study to contribute to developing a new concept of public policy in the implementation of fiscal decentralization policy. The method used in this study was a qualitative study, the exploratory design. The technique of collecting data through interviews, opservasi and documentation. This study focuses on the implementation of the fiscal decentralization policy, using the model of policy implementation according to Edward III would be unknown factors that play a role in the implementation of fiscal decentralization policy in South Sumatra Province. The results showed that the implementation of fiscal decentralization policy in South Sumatra province have not run optimally, the local fiscal management in support budgetair, especially for allocating expenses Pememerintah Development South Sumatra Province. To improve the implementation of fiscal decentralization policy in South Sumatra provincial government can be achieved through increased understanding of the capabilities and behavior of the actors implementing consistent policies, commitments and responsibilities of local government as the organizational level to allocate all budgets, establishing clarity of authority, work methods and procedures, and standards of clarity used as guidelines in implementation of the policy.
\end{abstract}

keywords : Implementation, Policies, Decentralization, Fiscal, South Sumatra

\section{PENDAHULUAN}

Undang - Undang Dasar 1945 pasal 33 sebagai landasan bagi system ekonomi Pancasila, yang lebih dikenal dengan demokrasi ekonomi. Mempunyai tujuan memberikan kemakmuran bagi semua orang, sedangkan pembangunan ekonomi nasional harus dilandasi moral kehidupan bangsa yang menjiwai. Untuk itu diharapkan semua lapisan masyarakat ikut serta dalam pembangunan. Dalam rangka merespon kondisi tersebut maka pemerintah telah menggulirkan kebijakan otonomi daerah yang dilaksanakan secara serempak di seluruh wilayah Indonesia. Kebijakan tersebut menimbulkan beberapa konsekuensi, baik dari aspek perangkat dan pembiayaan, seperti dikemukakan oleh Koswara ( 1997 : 20 ) sebagai berikut:

"Secara teoritis penyerahan otonomi kepada daerah harus pula dibarengi dengan penyerahan perangkat sebagai sarana dalam menjalankan otonomi daerah. Salah satunya dan merupakan faktor yang sangat menentukan dalam pelaksanaan otonomi daerah adalah pembiayaan". Umumnya pelaksanaan otonomi daerah belum mengacu pada kemandirian pembiayaan, ketergantungan pemerintah daerah pada pemerintah Pusat masih sangat tinggi dalam bentuk subsidi dan bantuan pembangunan. Prinsip pemencaran kekuasaan melalui desentralisasi tersebut melahirkan otonomi daerah, yang dalam penyelenggaraannya pada hakikatnya merupakan penerapan Teori areal division of power yang membagi kekuasaan dan pemerintahan daerah di lain pihak. Dengan demikian, maka" pemberian otonomi kepada daerah berdasarkan asas desentralisasi”( Ndraha, 1997 : 113 ). Otonomi terlihat dari asal-usulnya dapat didefinisikan dalam bentuk otonomi berian. Otonomi daerah adalah kewenangan daerah otonom untuk mengatur dan 
mengurus kepentingan masyarakat setempat menurut prakarsa sendiri berdasarkan aspirasi masyarakat sesuai dengan peraturan perundang-undangan. Oleh karena itu, tugas pemerintahan pada hakekatnya adalah mengatur dan melayani masyarakat dengan sebaik-baiknya. Komitmen ini hanya bisa terlaksana jika ada interaksi dari masyarakat yang merasa bahwa pemerintahannya telah berjalan dan mengarah pada upaya untuk melindungi dan melayaninya. Apabila kondisi ini tercipta, maka akan memberi kesempatan kepada masyarakat untuk mengembangkan daya kreativitasnya, karena itu tuntutan dan kebutuhan masyarakat akan pemenuhan layanan yang berkualitas merupakan kewajiban pemerintah untuk menyediakannya. Desentralisasi fiskal adalah salah satu instrument yang digunakan oleh pemerintah dalam mengelola pembangunan guna mendorong perekonomian daerah maupun nasional. Maka salah satu aspek dalam otonomi daerah adalah desentralisasi fiskal ( fiscal decentralization ).

Implementasi kebijakan desentralisasi fiskal merupakan suatu aktivitas penyampaian atau pelaksanaan kebijakan yang telah ditetapkan untuk mencapai tujuan dan sasaran yang di kehendaki maka perlu diwujudkan dalam kegiatan-kegiatan pelayanan publik yang nyata dan bermakna bagi masyarakat maupun pemerintah itu sendiri. Beberapa bentuk kegiatan yang telah dilakukan Pemerintah Provinsi Sumatera Selatan, melalui perangkat daerah yakni Dinas Pendapatan Daerah sebagai operasionalisasi dari kebijakan desentralisasi fiskal yaitu: bidang manajemen keuangan daerah. Berdasarkan pasal 157 Undang - Undang Nomor 32 tahun 2004 sebagaimana pengganti Undang-Undang Nomor 22 Tahun 1999 tentang Pemerintah Daerah, diatur bahwa sumber pendapatan daerah terdiri dari tiga kelompok:

Pertama, Pendapatan Asli Daerah (PAD) yang terdiri dari: (1) hasil pajak daerah; (2) hasil retribusi daerah; (3) hasil pengelolaan kekayaan daerah yang dipisahkan; dan (4) lain-lain PAD yang sah. Kedua, Dana perimbangan yang terdiri atas : (1) Dana bagi Hasil (DBH) yang bersumber dari: (a) pajak terdiri atas Pajak bumi dan Bangunan (PBB), Bea Perolehan Hak Atas Tanah dan Bangunan (BPHTB), Pajak Penghasilan (PPh) Pasal 25 dan Pasal 29 Wajib Pajak Orang Pribadi Dalam Negeri dan PPh Pasal 21 dan (b) bersumber dari SDA berasal dari kehutanan, pertambangan umum, perikanan, pertambangan minyak bumi, pertambangan gas bumi, dan pertambangan panas bumi; (2) Dana Alokasi Umum (DAU), dan (3) Dana Alokasi Khusus (DAK),Ketiga, lain-lain pendapatan daerah yang sah.

Anggaran Pendapatan dan Belanja Daerah ( APBD ) merupakan instrument dari ketepatan pengambilan kebijakan di bidang hubungan keuangan antara psat dan daerah. Dimana besaran jumlah uang dan pesetase dari ketiga sumber pendapatan daerah di atas. Maka dari hasil pengamatan di lapangan menunjukkan bahwa besaran APBD Provinsi Sumatera Selatan, tahun 2005 sebesar Rp 1.069.112.436.390,85; dan tahun 2006 sebesar Rp 1377.594.977.539,23; serta tahun 2007 sebesar 1.866.517822.444,37. Besaran persentase PAD terhadap APBD tahun 2005 sebesar 46,13\% ; dan tahun 2006 sebesar 42,88\% ; serta tahun 2007 39,77\%. Sedangkan persentase Dana Perimbangan terhadap APBD pada tahun 2005 sebesar $53,87 \%$; dan tahun 2006 sebesar 57,12\% ; serta pada tahun 2007 sebesar $60,23 \%$.

Berdasarkan uraian tersebut diatas, maka dapat dirumuskan masalah ( problem statement) yaitu : bahwa implementasi kebijakan desentralisasi fiskal di Provinsi Sumatera selatan menunjukkan bahwa dalam pengelolaan APBD belum optimal dalam mendukung budgetair, terutama untuk mengalokasikan pengeluaran pembangunan, Sedangkan dalam rangka implementasi kebijakan desentralisasi fiskal, Pemerintah Daerah Provinsi Sumatera Selatan diharapkan memiliki kemandirian yang lebih besar. Akan tetapi, saat ini masih banyak masalah yang dihadapi pemerintah daerah terkait dengan upaya meningkatkan penerimaan daerah, antara lain :

1. Kualitas layanan publik yang masih memprihatinkan menyebabkan produk layanan publik yang sebenarnya dapat dijual ke masyarakat direspon secara negatif. Keadaan tersebut juga menyebabkan keengganan masyarakat untuk membayar pajak dan retribusi daerah

2. Lemahnya infrastruktur prasarana dan sarana umum;

3. Berkurangnya dana bantuan dari pusat (DAU dari pusat yang tidak mencukupi ).

4. Hak untuk mendapatkan bagi hasil dari sumbersumber daya nasional yang berada di daerah dan dana perimbangan belum berjalan dengan optimal

5. Adanya desentralisasi fiskal dalam penyelenggaraan otonomi daerah, memberikan hak bagi pemerintah daerah untuk mendapatkan sumbersumber keuangan.

Menghadapi berbagai permasalahan di atas diperlukan suatu dasar Perumusan masalah implementasi kebijakan desentralisasi fiskal dalam pelaksanaan otonomi daerah di Sumatera Selatan, pada dasarnya bagaimana untuk memecahkan masalah kekurangan pendapatan, mengatasi eksternalitas dan melakukan redistribusi pendapatan nasional, serta menstabilkan ekonomi makro diseluruh Sumatera Selatan demi tercapainya penguatan dan stabilitas ekonomi secara nasional. Sertan faktor - faktor apa saja yang menyebabkan kurang optimalnya implementasi kebijakan desentralisasi fiskal di sumatera selatan.

Dalam studi implementasi kebijakan publik yang lebih realitas, Abidin (2004 : 191-197) lebih mengapresiasikan dukungan keberadaan faktor internal dan eksternal kebijakan proses implementasi kebijakan dengan pemikiran teoritik sebagai berikut :

1. Bahwa proses implementasi kebijkan ditentukan oleh dukungan dua faktor, yaitu faktor internal dan faktor eksternal. Faktor internal meliputi substansi kebijakan dan dukungan sumber daya, sedangkan faktor eksternal adalah meliputi kondisi lingkungan dan dukungan masyarakat.

2. Dukungan faktor internal kebijakan secara elaboratif meliputi:

(1). Subtansi kebijakan, bahwa suatu kebijakan dianggap berkualitas dan mampu dilaksanakan jika memiliki substansi : 
a). Tujuan,bahwa tujuan yang ingin dicapai atau alasan yang dipakai untuk membuat kebijakan itu dapat dikatakan baik, jika: (1) Rasional, artinya tujuan dapat dipahami atau diterima oleh akal sehat; (2) Diinginkan ( desirable), artinya tujuan kebijakan itu memenuhi kepentingan orang banyak atau dapat memenuhi kepentingan masyarakat.

b). Asumsi, bahwa asumsi yang dipakai dalam proses perumusan kebijakan itu realistis atau tidak mengada-ada.

c). Informasi, bahwa informasi yang digunakan cukup lengkap dan benar atau tidak kadaluarsa ( out of date ). Kebijakan yang didasarkan pada informasi yang kurang lengkap adalah tidak tepat.

2. Sumber daya, yaitu meliputi :

1. Sumber Daya Aparatur, yaitu dukungan aparat pelaksana kebijakan;

2. Anggaran, yaitu dukungan biaya bagi pelaksanaan kebijakan;

3. Sarana, yaitu dukungan peralatan bagi pelaksanaan kebijakan.

3. Dukungan faktor eksternal kebijakan secara elaboratif meliputi :

1.Kondisi lingkungan kebijakan, yaitu menyangkut kondisi sosial politil, dan ekonomi.

2.Dukungan masyarakat, yaitu dukungan masyarakat sebagai sasaran ( objek ) kebijakan yang diimplementasikan.

\section{Konsep Desentralisasi Fiskal}

Sejarah telah mencatat bahwa desentralisasi keuangan atau yang lebih dikenal dengan desentralisasi fiskal telah muncul sebagai wawasan baru dalam kebijakan negara pada era 1970-an. Kuncoro (1995:4) menyatatahan tumbuhnya perhatian terhadap desentralisasi fiskal disebabkan oleh dua hal: “(1) dikaitkan dengan gagalnya perencanaan terpusat yang populernya adalah strategi pertumbuhan dengan pemerataan (growth with equity); (2) adanya kesadaran bahwa pembangunan adalah suatu proses yang kompleks dan penuh ketidakpastian yang tidak dapat dengan mudah dikendalikan dan direncanakan dari pusat".

Karena alasan itulah, maka para ahli mengajukan berbagai alasan mendasar tentang pentingnya desentralisasi fiskal dalam perencanaan dan administrasi di negara-negara dunia ketiga. Sedangakan para ahli lebih memilih istilah desentralisasi fiskal untuk menjelaskan hal itu dibandingkan dengan desentralisasi keuangan. Karena baik fiskal maupun keuangan memiliki esensi yang sama, maka dalam pembahasan ini istilah desentralisasi fiskal akan lebih menonjol dibandingkan dengan desentralisasi keuangan. Hal itu tidak berbeda dengan pengertian hubungan fiskal antara pusat dan daerah yang memiliki makna sama dengan hubungan keuangan. Oleh sebab itu, kata fiskal baik yang diawali dengan kata hubungan maupun yang diawali dengan kata desentralisasi senantiasa diartikan dengan kata keuangan. Bukankah dalam kamus Bahasa Indonesia, kata fiskal diartikan sebagai "berkenaan dengan urusan pajak atau pendapatan negara" dan padanan yang pas untuk menyebutkan hal itu tidak lain adalah keuangan.

\section{Hubungan Keuangan Pusat dan Daerah.}

Secara teoritis, dalam konteks Negara kesatuan dikenal ada dua cara dalam menghubungkan pemerintah pusat dan daerah, yaitu sentralisasi dan desentralisasi. Cara pertama adalah sentralisasi. Dalam cara ini segala urusan ,tugas, fungsi, dan wewenang penyelenggaraan pemerintahan berada dalam genggaman pemerintah pusat yang pelaksanaannya dilakukan secara dekonsentrasi. Cara kedua, lawannya adalah desentralisasi di mana semua urusan, tugas, dan wewenang pelaksanaan pemerintahan diserahkan sepenuhnya kepada daerah.

Dasar Hukum hubungan pemerintah pusat dan daerah secara konstitusional diatur dalam pasal 18A ayat (2) Perubahan kedua UUD 1945., menyatakan: "Hubungan keuangan, pelayanan umum, pemanfaatan sumber daya alam dan sumber daya lainnya antara Pemerintah Pusat dan Pemerintah Daerah diatur dan dilaksanakan secara adil dan selaras berdasarkan Undang-undang”. Undang-Undang Nomor 32 Tahun 2004 mengatur dua faktor hubungan keuangan, yakni hubungan keuangan antara pusat dan daerah dan hubungan antar pemerintah daerah. Hubungan keuangan antara pusat dan daerah terdiri atas tiga cara :

Pertama, Pemberian sumber-sumber keuangan untuk menyelenggarakan urusan pemerintahan yang menjadi kewenangan pemerintahan daerah; Kedua, pengalokasian dana perimbangan kepada pemerintah daerah; Ketiga, pemberian pinjaman dan atau hiba kepada pemerintah daerah.

Pola hubungan pemerintah pusat dan daerah secara konstitusional diatur dalam pasal 18 UUD 1945.Namun jika kita kaitkan dengan konsep sentralisasi dan desentralisasi, dalam suatu sistem pemerintahan yang bertingkat seringkali muncul pembagian kewenangan yang bersifat paradox, misalnya dalam pelaksanaan otonomi daerah. Untuk memahami perbandingan antara sistem pemerintahan sentralistik dengan desentralistik dapat disimak dalam tabel ,1.

Tabel 1. Perbandingan Sistem Pemerintahan Sentralistik dan Desentralistik

\begin{tabular}{|c|c|}
\hline SENTRALISTIK & DESENTRALISTIK \\
\hline $\begin{array}{l}\text { Sebagian besar kebijakan ditentukan oleh pusat, } \\
\text { kewenangan daerahterbatas; }\end{array}$ & $\begin{array}{l}\text { Ada kewenangan yang luas bagi } \\
\text { daerah. }\end{array}$ \\
\hline $\begin{array}{l}\text { 1. Anggaran, mayoritas sumber penerimaan dan } \\
\text { alokasi pengeluaran dikuasai pusat. }\end{array}$ & $\begin{array}{l}\text { 1. Anggaran, adakeseimbangan fiskal } \\
\text { pusat-daerah. }\end{array}$ \\
\hline $\begin{array}{l}\text { 2. Keleluasan daerah dalam menggunakan transfer } \\
\text { dari pusat terbatas (specific/conditional grant) }\end{array}$ & $\begin{array}{l}\text { 2. Ada keleluasan daerah dalam } \\
\text { memanfaatkan transfer dari pusat } \\
\text { (block unconditional grants) }\end{array}$ \\
\hline Alasan: & Alasan: \\
\hline Skala ekonomis, efisiensi, & efisiensi, akuntabilitas, \\
\hline faham sosialis. & manageability, otonomi. \\
\hline
\end{tabular}

Sumber: Hyman (1999: 633); Shah (1994b : 6); Bird \& Vaillancourt (2000:30). 
Sedangkan menurut Davey (1988:179) bahwa: Hubungan keuangan antara Pusat dan Daerah adalah menyangkut pembagian tanggung jawab untuk melaksanakan kegiatan-kegiatan tertentu antara tingkat-tingkat pemerintah dan pembagian sumber penerimaan untuk menutup pengeluaran akibat kegiatan-kegiatan itu. Maka tujuan utama dari hubungan antara Pusat dan Daerah menurut Davey diatas adalah mencapai perimbangan antara berbagai pembagian, disamping itu agar antara potensi dan sumber daya masing-masing daerah dapat sesuai. Berkaitan dengan pendapat Davey diatas, maka intisari dari hubungan Pusat dan Daerah adalah menyangkut pembagian kekuasaan. Unsur yang sangat penting dalam menjalankan kekuasaan yang berkaitan dengan hubungan tersebut adalah mengenai hak mengambil keputusan mengenai anggaran pemerintah, termasuk di dalamnya adalah bagaimana memperoleh dan membelanjakannya. Dengan alasan itulah, maka Davey (1988:179) berpendapat bahwa hubungan keuangan antara Pusat dan Daerah mencerminkan tujuan politik yang mendasar sekali, karena perannya dalam menentukan bobot kekuasaan yang dijalankan Pemda dalam suatu sistem pemerintahan.

\section{Konsep Keuangan Daerah}

Keuangan daerah adalah alat fiskal pemerintah daerah, yang merupakan bagian integral dari keuangan Negara dalam mengalokasikan sumber-sumber ekonomi memeratakan hasil pembangunan dan menciptakan stabilitas sosial politik. Peranan keuangan daerah makin penting, selain karena keterbatasan dana yang dapat dialihkan ke daerah berupa subsidi dan sumbangan tetapi oleh makin kompleks nya masalah yang dihadapi daerah. Menurut Redjo (1998:81) bahwa: perencanaan dibidang peningkatan keuangan daerah, diter-jemahkan sebagai upaya-upaya ekstensifikasi dan intensifikasi Pendapatan Asli Daerah sediri (PADS), dengan berpedoman pada pengembangan dan penggalian sumber-sumber pendapatan. Lebih lanjut di kemukakan bahwa Pendapatan Asli Daerah itu, bersumber pada lima unit sumber pendapatan, yaitu : Pajak Daerah, Retribusi Daerah, Laba Perusahaan Daerah, Penerimaan Dinas-Dinas serta penerimaan lain-laian. Oleh karena itu menurut Nazara (1997:17) maka pemerintah daerah menurunkan 5 kebijakan pokok dibidang keuangan yaitu:

1. Kebijakan meningkatkan Pendapatan Asli Daerah; Sumber pajak retribusi, penerimaan hasil pajak dan bukan pajak subsidi dan bantuan BUMD.

2. Kebijakan pengeluaran Pemda diarahkan untuk meningkatkan perekonomian rakyat memperluas lapangan kerja, mendorong usaha pemerataan sektor swasta, produktifitas, komoditi ekspor dan pariwisata.

3. Kemampuan organisasi pemerintah daerah, termasuk manajemen, struktur dan perencanaan.

4. Peningkatan system informasi keuangan daerah dan pengendalian pembangunan.

5. Kebijakan untuk mendorong ikut serta swasta dalam pelayanan masyarakat di daerah.

\section{Implementasi Kebijakan Desentralisasi Fiskal}

Dalam studi implementasi kebijakan publik yang lebih realitas, Abidin (2004:191-197) lebih mengapresiasikan dukungan keberadaan faktor internal dan eksternal kebijakan proses implementasi kebijakan dengan pemikiran teoritik sebagai berikut :

1. Bahwa proses implementasi kebijkan ditentukan oleh dukungan dua faktor, yaitu faktor internal dan faktor eksternal. Faktor internal meliputi substansi kebijakan dan dukungan sumber daya, sedangkan faktor eksternal adalah meliputi kondisi lingkungan dan dukungan masyarakat.

2. Dukungan faktor internal kebijakan secara elaboratif meliputi:

(1). Subtansi kebijakan, bahwa suatu kebijakan dianggap berkualitas mampu dilaksanakan jika memiliki substansi :

a). Tujuan,bahwa tujuan yang ingin dicapai atau alasan yang dipakai untuk membuat kebijakan itu dapat dikatakan baik, jika: (1) Rasional, artinya tujuan dapat dipahami atau diterima oleh akal sehat; (2) Diinginkan (desirable), artinya tujuan kebijakan itu memenuhi kepentingan orang banyak atau dapat memenuhi kepentingan masyarakat.

b). Asumsi, bahwa asumsi yang dipakai dalam proses perumusan kebijakan itu realistis atau tidak mengada-ada.

c). Informasi, bahwa informasi yang digunakan cukup lengkap dan benar atau tidak kadaluarsa (out of date). Kebijakan yang didasarkan pada informasi yang kurang lengkap adalah tidak tepat.

(2). Sumber daya, yaitu meliputi :

a). Sumber Daya Aparatur, yaitu dukungan aparat pelaksana kebijakan;

b). Anggaran, yaitu dukungan biaya bagi pelaksanaan kebijakan;

c). Sarana, yaitu dukunganperalatan bagi pelaksanaan kebijakan.

3. Dukungan faktor eksternal kebijakan secara elaboratif meliputi :

(1).Kondisi lingkungan kebijakan, yaitu menyangkut kondisi sosial politik, dan ekonomi.

(2).ukungan masyarakat, yaitu dukungan masyarakat sebagai sasaran (objek) kebijakan yang diimplementasikan.

Sesuai dengan landasan teori di atas, maka untuk menjawab pertanyaan penelitian berkaitan dengan desentralisasi fiskal dapat diartikan sebagai pelimpahan kewenangan di bidang penerimaan yang sebelumnya tersentralisasi baik secara administrasi dan pemanfaatannya diatur atau dilakukan oleh Pemerintah Pusat. Dengan terjadinya pelimpahan sebagian kewenangan terhadap sumber-sumber penerimaan Negara kepada pemerintahan di daerah, diharapkan daerah akan dapat melaksanakan tugas-tugas rutin, pelayanan publik dan meningkatkan investasi yang produktif (capital investment). Oleh karena itu salah satu makna dari desentralisasi fiskal dalam bentuk pemberian otonomi dalam kaitan dengan kebijakan keuangan Negara yaitu untuk mewujudkan ketahanan fiskal yang berkelanjutan (fiscal sustainability) dan memberikan stimulus terhadap aktifitas perekonomian 
masyarakat, maka dengan kebijakan desentralisasi fiskal diharapkan akan menciptakan pemerataan kemampuan keuangan antar daerah yang sepadan dengan besarnya kewenangan urusan pemerintahan yang diserahkan kepada daerah otonom.

Desentralisasi Fiskal juga merupakan salah satu pilar dalam memelihara kestabilan kondisi ekonomi nasional, karena dengan adanya transfer dana ke daerah akan mendorong aktifitas perekonomian masyarakat di daerah, agar manfaat yang dihasilkan dapat dinikmati oleh rakyat di daerah yang bersangkutan. Ini berarti bahwa Pemerintah Daerah secara finansial harus bersifat independen terhadap Pemerintah Pusat dengan cara sebanyak mungkin menggali sumbersumber Pendapatan Asli Daerah seperti Pajak, retribusi dan sebagainya.

\section{Konsep Manajemen Keuangan Daerah}

Konsep manajemen keuangan daerah secara garis besar dapat dibagi menjadi dua, yaitu managemen penerimaan daerah dan managemen pengeluaran daerah. Dalam rangka melaksanakan otonomi daerah kedua komponen itu sangat besar pengaruhnya (Mardiasmo, 2002 : 104). Adapun konsep manajemen keuangan daerah itu secara garis besar dapat dibagi menjadi dua bagian, yaitu: Manajemen penerimaan daerah dan manajemen pengeluaran daerah. Sementara itu secara sederhana pengertian manajemen adalah suatu kegiatan yang dilakukan untuk mencapai tujuan yang telah ditetapkan secara efektif dan efisien Sedangkan manajemen mempelajari bagaimana menciptakan efektivitas usaha (doing, ring thing) secara efisien (doing thing right) dan produktif, dalam rangka mencapai tujuan organisasi yang telah ditetapkan (Ndraha : 2003 : 159). Sedangkan istilah keuangan oleh Kaho diartikan sebagai setiap hak yang berhubungan dengan masalah uang, antara lain berupa sumber pendapatan, jumlah uang yang cukup, dan pengelolaan keuangan yang sesuai dengan tujuan dan peraturan yang berlaku (Kaho, 2001:61). Sementara itu, keuangan daerah ( seperti dinyatakan dalam PP.Nomor 105 Tahun 2000 ) berarti semua hak dan kewajiban daerah dalam rangka penyelenggaraan pemerintahan daerah yang dapat dinilai dengan uang, (termasuk segala bentuk kekayan yang berhubungan dengan hak dan kewajiban daerah), dalam kerangka Anggaran Pendapatan dan Belanja Daerah (APBD).

Dari pengertian tersebut jelas bahwa faktor manajemen keuangan, khususnya keuangan daerah sangat besar pengaruhnya terhadap keberhasilan pelaksanaan desentralisasi fiskal. Oleh karena itu manajemen keuangan daerah merupakan salah satu pokok persoalan yang direformasi oleh UndangUndang Nomor 32 tahun 2004, tentang Pemerintah Daerah dan Undang-Undang Nomor 33 tahun 2004, tentang Perimbangan KeuanganAntara Pemerinta Pusat dan Daerah. Pentingnya manajemen keuangan dalam setiap kegiatan pemerintahan, karena hampir tidak ada kegiatan pemerintahan yang tidak membutuhkan biaya. Makin besar jumlah uang yang tersedia, makin banyak pula kemungkinan kegiatan atau pekerjaan yang dapat dilaksanakan. Demikian juga semakin baik pengelolaannya semakin berdayaguna pemakaian uang tersebut.

\section{Kebijakan Perimbangan Keuangan.}

Sesuai dengan Undang-Undang Nomor 32 tahun 2004 dan Undang-Undang Nomor 33 tahun 2004, bahwa perimbangan keuangan pusat dan daerah dalam rangka pelaksanaan desentralisasi fiskal mengandung pengertian bahwa kepada daerah diberikan kewenangan untuk memanfaatkan sumber keuangan sendiri dan didukung dengan perimbangan keuangan antara pusat dan daerah. Kebijaksanaan perimbangan keuangan antara pusat dan daerah dilakukan dengan mengikuti pembagian kewenangan atau money follows function. Hal ini berarti bahwa hubungan keuangan antara pusat dan daerah perlu diberikan pengaturan, sehingga kebutuhan pengeluaran yang akan menjadi tanggung jawab daerah dapat dibiayai dari sumber-sumber penerimaan yang ada. Sejalan dengan pembagian kewenangan yang disebutkan diatas, maka pengaturan pembiayaan daerah dilakukan berdasarkan asas penyelenggaraan pemerintahan tersebut. Pembiayaan penyelenggaraan pemerintahan berdasarkan asas desentralisasi dilakukan atas beban APBN dan pembiayaan penyelenggaraan pemerintahan dalam rangka tugas pembantuan dibiayai atas beban anggaran tingkat pemerintahan yang menugaskan.

Keberadaan Undang-Undang Nomor 33 tahun 2004 salah satunya dimaksudkan untuk mengatasi persoalan tersebut, sehingga tercipta sistem pembiayaan daerah yang adil, proposional, rasional, transparan, partisipatif dan bertanggung jawab. Caranya dengan mewujudkan sistem perimbangan keuangan antara pemerintah pusat yang adil dan selaras dengan memberikan kepastian sumber keuangan yang berasal dari daerah yang bersangkutan. Hal itu selaras dengan prinsip kebijakan perimbangan dalam pasal 3 Undang-Undang Nomor 33 tahun 2004 yaitu : "Pertama, peningkatan PAD bertujuan memberikan kewenangan kepada pemerintah daerah untuk mendanai pelaksanaan otonomi daerah sesuai dengan potensi daerah sebagai perwujudan desentralisasi. Kedua, dana perimbangan bertujuan mengurangi kesenjangan fiskal antara pemerintah dan pemerintahan daerah. Ketiga, Pinjaman daerah bertujuan memperoleh sumber pembiayaan dalam rangka penyelenggaraan urusan pemerintahan daerah. Keempat, lain-lain pendapatan bertujuan memberi peluang kepada daerah untuk memperoleh pendapatan selain pendapatan yang disebutkan diatas".

Sedangkan Devas. Nich.et.al. (1989:280) mengemukakan unsur-unsur sistem keuangan Pemerintah Daerah dapat digolongkan kedalam dua kelompok yakitu : “(1) Unsur Berkala dan unsur hukum, unsur berkala meliputi unsur-unsur yang menjadi bagian dari kegiatan-kegiatan berkala dalam setahun, yakni menyusun program dan anggaran, pengeluaran dan penerimaan anggaran, urusan uang keluar dan uang masuk, mencatat dan melaporkan transaksi keuangan. Unsur hukum mencakup unsur-unsur pengaturan dan pemantauan kegiatan berkala, yakni : Undang- 
Undang, dan Peraturan keuangan, transaksi dan pemeriksaan keuangan dari dalam; (2) Unsur-unsur luar dan dalam: unsur luar meliputi pengawasan yang dikenakan terhadap pemerintah daerah oleh pejabatpejabat pengawas yang lebih tinggi (Pemerintah Pusat) berdasarkan hukum dan peraturan yang berhak, ratifikasi mengenai anggaran dan peraturan keuangan, laporan kebutuhan dan pemeriksaan keuangan dari luar".

Sebagaimana pendapat diatas maka dapat disimpulkan bahwa dalam pengelolaan keuangan daerah perlu adanya suatu proses koordinasi yang jelas sehingga dapat tercipta sinergis didalam suatu organisasi pemerintah daerah, yang pada akhirnya akan menuju pada manajemen keuangan daerah yang professional. Untuk itu perlu adanya suatu pembaharuan sesuai dengan tuntutan paradigma dalam proses pengelolan keuangan daerah itu sendiri. Berkaitan dengan tuntutan perubahan tersebut Mardiasmo (2002:117) menjelaskan bahwa perencanaan APBD dengan paradigma baru adalah sebagai berikut: “(1) APBD yang berorientasi pada kepentingan publik; (2) APBD yang disusun dengan pendekatan kinerja; (3) Terdapat keterkaitan yang erat antara pengambil kebijakan (decision Maker) di DPRD dengan perencanaan operasional oleh pemerintah daerah dan penganggaran oleh unit kerja; (4) Terdapat upaya untuk mensinergiskan hubungan antara APBD, system dan prosedur pengelolaan keuangan daerah, lembaga pengelolaan keuangan daerah dan unit-unit pengelolaan layanan publik dalam pengambilan kebijakan".

Berdasarkan pemikiran konsepsional atau teoritik yang dikemukakan oleh para pakar dalam studi proses kebijakan publik sebagaimana diuraikan tersebut diatas, nampaknya teori implementasi kebijakan dari Abidin (2004:191-197) lebih konprehensif dan realistis dipandang dari perspektif manajerial maupun kondisional bagi studi kebijakan yang aktual dan relepan sebagai landasan analisis implementasi kebijakan desentralisasi fiskal dengan intisari teoritik sebagai berikut:

1).Bahwa proses implementasi kebijkan ditentukan oleh dukungan dua faktor, yaitu faktor internal dan faktor eksternal. Faktor internal meliputi substansi kebijakan dan dukungan sumber daya, sedangkan faktor eksternal adalah meliputi kondisi lingkungan dan dukungan masyarakat.

2).Dukungan faktor internal kebijakan secara elaboratif meliputi:

(1). Subtansi kebijakan, bahwa suatu kebijakan dianggap berkualitas dan mampu dilaksanakan jika memiliki substansi :

a). Tujuan,bahwa tujuan yang ingin dicapai atau alasan yang dipakai untuk membuat kebijakan itu dapat dikatakan baik, jika:

b). Nasional, artinya tujuan dapat dipahami atau diterima oleh akal sehat; (2) Diinginkan (desirable), artinya tujuan ke- bijakan itu memenuhi kepentingan orang banyak atau dapat memenuhi kepentingan masyarakat.

c). Asumsi, bahwa asumsi yang dipakai dalam proses perumusan kebijakan itu realistis atau tidak mengada-ada.

d). Informasi, bahwa informasi yang digunakan cukup lengkap dan benar atau tidak kadaluarsa (out of date). Kebijakan yang didasarkan pada informasi yang kurang lengkap adalahtidak tepat.

(2). Sumber daya, yaitu meliputi :

a). Sumber Daya Aparatur, yaitu dukungan aparat pelaksana kebijakan;

b). Anggaran, yaitu dukungan biaya bagi pelaksanaan kebijakan;

c). Sarana, yaitu dukungan peralatan dan pelaksanaan kebijakan.

(3). Dukungan faktor eksternal kebijakan secara elaboratif meliputi :

1). Kondisi lingkungan kebijakan,yaitu menyang kut kondisi Sosial politil, dan ekonomi.

2).Dukungan masyarakat, yaitu dukungan masyarakat sebagaisasaran (objek) kebijakanyang diimplementasikan.

Konstruksi teoritik tersebut kiranya cukup beralasan, karena dalam perspektifmanajemen, bahwa kebijakan merupakan instrument basis bagi manajemen untuk mensolusi berbagai permasalahan yang komplek, yang dihadapi dalam proses mencapai tujuan manajemen, inklusif dalam manajemen pemerintahan dengan memanfaatkan dukungan sumber daya yang dimiliki sebagaimana dikemukakan Fleet (1988:9) bahwa, manajemen adalah suatu kelompok aktivitas yang diarahkan kepada pemanfaatan sumber - sumber daya secara efektif serta efisisen dalam rangka mencapai sebuah tujuan atau lebih". Secara kondisio nal, bahwa efektifitas implementasi suatu kebijakan ditentukan pula oleh rialitas dukungan masyarakat yang teraktualisasi dalam bentuk partisipasi masyarakat, seperti dikemukakan Huntington dan Nelson (1990:1) bahwa: Partisipasi merupakan ciri khas dari masyarakat modern. Dinegara-negara yang belum modern, sebagian besar mesyarakatnya belum merasa penting untuk berpartisipasi dalam kebijakan pemerintah. Mereka belum merasa bahwa kebijakan pemerintah mempunyai pengaruh pada kehidupannya, apalagi untuk berpikir bahwa mereka mempunyai hak dan mampu mempengaruhi kebijakan pemerintah itu untuk kepentingannya.

Menurut Dye (1997:45) bahwa rencana atau perencanaan merupakan salah satu bagian dari komponen kebijakan. Penulis sangat tertarik memilih tiori Dye, karna Teori Dye adalah teori kebijakan bahwa penetapan rencana dalam konteks perencanaan penerimaan daerah retribusi daerah sudah tentu diungkapkan dalam kebijakan APBD melalui sebuah Peraturan Daerah. Kebijakan publik merupakan keputusan pemerintah untuk melakukan atau tidak melakukan tindakan untuk mencapai tujuan tertentu 
atau memecahkan masalah tertentu. Kebijakan daerah yang mengatur penyelenggaraan Desentralisasi fiskal merupakan salah satu jenis kebijakan publik yang ditetapkan oleh Pemerintah Keuangan daerah (termasuk dana otonomi khusus) pada dasarnya harus dikelola secara tertib, taat peraturan perundangundangan, efesien, ekonomis, efektif dan bertanggung jawab dengan memperhatikan asas keadilan, kepatutan dan manfaat untuk masyarakat yang dilakukan secara transparan dan akuntabel dengan memberikan akses informasi yang seluas-luasnya bagi masyarakat sejalan dengan prinsip-prinsip Good Governance. Sedangkan proses kebijakan yang saya nilai paling krusial adalah tahapan implementasi kebijakan yaitu tahapan dimana sebuah tujuan kebijakan akan dilaksanakan dengan seluruh sumber daya dan potensi yang ada maka penulis memilih teori (Edwards III,1980:51). Dari sudut ketatanagaraan yang dimaksud dengan desentralisasi adalah penyerahan kekuasaan pemerintah dari pusat kepada daerah untuk mengatur bagaimanapun baiknya sebuah kebijakan publik, kalau tidak dipersiapkan dan dilaksanakan dengan baik, maka apa yang menjadi tujuan tersebut tidak akan mampu tercapai dengan sempurna. Untuk itu, bukan saja pada tahap implementasi yang harus dipersiapkan dan direncanakan dengan baik, tetapi juga pada tahapan perumusan atau pembuatan kebijakan publik juga diantisipasi dengan melihat Faktor dominan yang terdiri atas: Komunikasi, sumber daya, disposisi, dan struktur birokrasi sebagaimana diungkapkan dalam Edward III (1980:37) merupakan kerangka analisa yang sangat penting. Kinerja keempat faktor tersebut sangat mempengaruhi implementasi kebijakan desentralisasi fiskal Dalam hal ketidak efektifan implementasi desentralisasi fiskal. dilihat dari kerangka Edward III adalah sebagai berikut:

1. Dari aspek komunikasi adalah bagaimana suatu produk kebijakan Desentralisasi fiskal di Provinsi Sumatera Selatan, baik dari tataran prinsip maupun operasional dapat disalurkan kepada seluruh pemangku kepentingan (stake holder) mungkin melalui berbagai upaya daerah. Dalam Kasus Provinsi Sumatera Selatan, sesuai dengan keterangan informan sebagai perwakilan pemangku kepentingan, di antaranya adalah; staf operasional lapangan/petugas keuangan di kabupaten bahwa selalu ada ketimpangan dalam penerimaan DAU dalam Hubungan keuangan antara Pemerintah Pusat dan Daerah, dimana terjadi pembagian kewenangan antara pemerintahan yang dikaitkan dengan sumber keuangan/ pembiayan. Untuk itu diperlukan kesamaan pemahaman antara jajaran syarat yang pen-ting dalam mentransformasikan kebijakan kepada pemangku kepentingan atau implementor atau aspirator di lapangan mencakup; cara penyaimpaian/penyebaran, kejelasan informasi, dan konsistensi informasi Pemerintahan Pusat terhadap Daerah
2. Dari aspek sumber daya adalah; mencakup kesiapan staf (SDM), sumber dana, informasi, kewenangan dan fasilitas. Dalam kasus Provinsi Sumatera Selatan, sesuai dengan kerangka yang bias dihimpun bahwa pada dasarnya kesiapan staf lebih dilihat dari hal kemauan dan kejujuran, mempunyai keahlian. Sumber dana merupakan hal yang penting, karena dengan sumber dana yang memadai maka Pemerintah Provinsi Sumatera Selatan bisa memberikan kelayakan dan kesejahteraan kepada pegawainya, terutama staf dilapangan. Selain itu dengan sumber dana yang cukup, maka dalam melaksanakan fungsi tersebut harus didukung sumber-sumber keuangan yang menjadi baik yang berasal dari Pendapatan Asli Daerah ( PAD), Dana Perimbangan, Pinjaman Daerah maupun lain-lain penerimaan yang sah. Untuk Peranan Pemerintah daerah sebagai (1) ungkapan dari kemauan dan identitas masyarakat setempat. (2) Pemerintah daerah pada dasarnya adalah lembaga untuk menyelenggarakan layananlayanan tertentu untuk daerah, dan sebagai alat yang tepat untuk menebus biaya memberikan layanan yang semata-mata bermanfaat untuk daerah. Sedangkan informasi tentang kewenangan pada setiap tingkatan implementor/operator dilapangan seringkali diabaikan dalam melaksanakan tugas sehingga terkesan tumpang tindih, sebagaimana diutarakan oleh informan penelitian ini.

3. Dari aspek disposisi atau sikap pelaksana adalah; sikap kesadaran dan tanggung jawab implementator/ operator pemerintah daerah di lapangan dalam melaksanaakan tugasnya belum memadai, hal ini sudah tentu dipengaruhi oleh kondisi kedua aspke sebelumnya; yaitu komunikasi dan sumber daya yang belum cukup memadai sebagaimana diuraikan diatas.

4. Dari aspek struktur birokrasi adalah; merupakan urat nadi terhadap berjalannya ketiga aspek diatas; komunikasi, sumber daya dan sikap pelaksana. Semakin rumitnya dan luasnya rentang kendali struktur birokrasi, maka dimungkinkan komunikasi akan terhambat, sumber daya tidak bias tidak biasa dimanfaatkan secara penuh, dan sikap atau respon pelaksana akan kurang maksimal.

Dari pendapat diatas dapat dijelaskan sebagi berikut:

1. Implementasi kebijakan desentralisasi fiskal me rupakan dampak atas pelaksanaan kebijakan yang dibuat implementasi tersebut sebaiknya perlu me ngacu kepada kerangka Edward III;

2. Kinerja implementasi kebijakan; apakah itu baik atau buruk akan berdampak kepada kwalitas pelayanan yang secara operasional menjadi tugas staf teknis (operasional) pada unit dimana objek Pendapatan Daerah dikelola.

3. Dalam hal praktek di lapangan, melibatkan baik sengaja maupun tidak sengaja akan partisipasi masyarakat setempat, namun demikian dalam koridor terkendali;

4. Operasional pelaksanaan tersebut, baik yang langsung dikelola oleh unit Provinsi Sumatera 
Selatan maupun Kabupaten/Kota yang menjadi kendala dalam pencapaian kinerja implementasi kebijakan yang diindikasikan dengan kinerja target dan realisasi Pendapatan Daerah Provinsi Sumatera Selatan.

5. Dengan demikian untuk meningkatkan kinerja pendapatan daerah perlu meningkatkan peranan unit yang bertanggung jawab terhadap setiap sektor pendapatan daerah, seperti Dinas Pendapatan Daerah, maupun unit-unit pengelola yang menyangkut setiap sektor pendapatan daerah Provinsi Sumatera Selatan. Sesuai Undang-Undang Nomor 32 tahun 2004 dan Undang-Undang Nomor 33 tahun 2004, maka Pemerintah Daerah memiliki kewenangan untuk melaksanakan kegiatannya dan menjalankan pembangunan serta kewenangan yang lebih luas dalam mendapatkan sumber-sumber pembiayaaan, baik yang berasal dari daerah itu sendiri maupun dana yang berasal dari APBN. Menurut Peraturan Pemerintah Nomor 104 tahun 2000 sebagaimana telah disempurnakan dengan Peraturan Pemerintah Nomor 55 tahun 2005 tentang Dana Perimbangan. Dinyatakan ada 4 (empat) sumber dana perimbangan dari Pemerintah Pusat, yang terdiri dari :

1. Dana Bagi Hasil adalah dana yang bersaumber dari APBN yang dibagihasilkan kepada Daerah berdasarkan angka persentase tertentu dengan memperhatikan potensi daerahpenghasil;

2. Dana Alokasi Umum bertujuan untuk pemerataan kemampuan keuangan antar daerah melalui penerapan formulasi yang mempertimbangkan kebutuhan belanja pegawai, kebutuhan fiskal, dan potensi daerah;

3. Kebutuhan daerah dicerminkan dari luas daerah, keadaan geografis, jumlah penduduk, tingkat kesehatan dan kesejahteraan masyarakt di daerah, dan tingkat pendapatan masyarakat di daerah. Sedangkan kapasitas fiskal dicerminkan dari Pendapatan Asli Daerah, Dana Bagi Hasil Pajak, dan Sumber ya Alam;

4. Dana Alokasi Khusus dimaksudkan untuk mendanai kegiatan khusus yang menjadi urusan daerah dan merupakan prioritas nasional, sesuai dengan fungsi yang merupakan perwujudan tugas kepemerintahan di bidang tertentu khususnya dalam upaya pemernuhan kebutuhan sarana dan prasarana pelayanan dasar masyarakat.

Melalui penyempurnaan prinsip-prinsip, mekanisme, dan penambahan persentase beberapa komponen dana perimbangan diharapkan daerah dapat meningkatkan fungsi pemerintahan daerah sebagai ujung tombak dalam memberikan pelayanan kepada masyarakat, misalnya kebijakan dalam pelayanan infrastruktur dan Pajak Kendaraan di Provinsi Suma tera Selatan. Pada dasarnya, jenis infrastruktur dapat dibedakan menjadi infrastruktur pusat dan infrastruktur daerah.

Hipotesis kerja (working hypothesis) yang merupakan panduan dalam melakukan kegiatan penelitian yaitu: "Implementasi kebijakan desentralisasi fiskal akan optimal meningkatkan pendapatan daerah di Provinsi Sumatera Selatan apabila memperhatikan faktor komunikasi, sumber daya, disposisi atau sikap pelaksana, dan struktur birokrasi.

\section{METODE}

Desain penelitian ini menggunakan pendekatan atau metode kualitatif, yang menghasilkan data kualitatif dalam bentuk kategorisasi, karakteristik berwujud kata-kata atau tulisan/ucapan dan perilaku subjek yang diamati (Riduwan,2002:5) dengan mengandalkan human instrument dalam mengakumulasi data empirik melalui wawancara yang mendalam (in depth interview), dan selanjutnya dilakukan analisis induktif untuk dideskipsikan guna memperoleh deskripsi faktual yang utuh, yang menjelaskan proses implementatif dan hasilnya, sebagaimana dikemukakan oleh Bogdan \& Taylor (1992:22) bahwa, " melalui pendekatan kualitatif diharapkan mampu menghasilkan suatu uraian mendalam tentang ucapan, tulisan, dan/atau perilaku yang dapat di amati dari sudut individu, kelompok, masyarakat, dan/atau dikaji dari sudut pandang yang utuh, konfrehensif, dan holistik".

Dalam kontek tersebut, Maxwll (1996:17) memperkuat, the strengths of qualitative research derive primarily from its inductive approach, its focus on specific situations or people, and its emphasis on words rather than number". Senada dengan pe-mikiran metodologis tersebut Locke, Spriduso dan Silferman sebagaimana dikutip Creswell (1994:147) mengemukakan bahwa: "Qualitative research is interpretative research. As such, the biases, values and judgment of the researches become stated explicitly in the research report. Such openness is considered to be useful and positive". Artinya, aktivitas penelitian dicirikan oleh kegiatan mengumpulkan, menggambarkan dan menafsirkan data tentang situasi yang dialami, hubungan tertentu, kegiatan, pandangan, sikap yang ditunjukkan atau tentang kecenderungan yang tampak dalam proses yang sedang berlangsung pertentangan yang meruncing serta kerjasama yang dijalankan.

Kemudian menurut Moleong (1997:3) metode penelitian kualitatif sebagai prosedur penelitian yang menghasilkan data deskriptif berupa kata tertulis atau lisan dari orang-orang dan perilaku yang diamati. Penelitian kualitatif lebih menghendaki arah bimbingan penyusunan teori subtantif yang berdasarkan data. Di gunakan metode penelitian ini sesuai dengan apa yang dikatakan Strauss dan Corbin (1990:19): "Qualitative methods can be used to uncover and understand what lies behing any phenomenon anout which little is yet known...... Qualitative methods can give the indicative details of phenomenon that are difficult to convey with quantitative methods".

Dengan demikian, aktivitas penelitian dicirikan oleh kegiatan Pengumpulan data dilaksanakan sesuai karakteristik dan situasi serta keadaan yang dihadapi dengan secara langsung terlihat di lokasi penelitian melalui (observation), yaitu melihat, mendengar dan bertanya. Penelitian kualitatif ini juga ditekankan kepada segi proses dari hasil penelitian yang mengungkapkan permasalahan mengenai apa adanya (das-sain) sesuai dengan kenyataan 
yang ada di lapangan penelitian melalui kata-kata tertulis atau lisan dari orang dan perilaku yang dapat diamati, kemudian mendeskripsikan upaya pemecahan masalah dengan jalan menggambarkan secara akurat dari beberapa fenomena, kelompok atau individu, dan hasil penemuan yangada berdasarkan fakta-fakta, serta mempelajari dan mendalami secara intensif tentang implementasi kebijakan desentralisasi fiskal di Provinsi Sumatera Selatan.

\section{HASIL DAN PEMBAHASAN}

\section{Kondisi Ekonomi Provinsi Sumatera Selatan.}

Dalam penelitian ini, yang dimaksukkan ke dalam Pengelolaan keuangan pemerintah daerah di Provinsi Sumatera Selatan dapat di telusuri dari skema keuangan pemerintah daerah yang tertuang secara resmi dalam Undang-Undang Nomor 25 tahun 1999 dan dilengkapi dengan Undang-Undang Nomor 34 Tahun 2000. Kini, peraturan tersebut telah disempurnakan sehingga penerimaan pemerintahan daerah dapat disimak dalam Undang-Undang Nomor 32 dan 33 Tahun 2004. Disebut dalam Undang-Undang tersebut bahwa sumber penerimaan daerah dalam implementasi kebijakan desentralisasi fiskal terdiri atas pendapatan daerah dan pengeluaran daerah (pembiayaan daerah). Pendapatan Daerah bersumber dari pendapatan asli daerah (PAD), dana perimbangan, dan lainlain pendapatan. Pengeluaraan (pembiayaan) dapat bersumber dari sisa lebih perhitungan anggaran daerah, penerimaan pinjaman daerah, dana cadangan daerah, dan hasil penjualan kekayaan daerah yang dipisahkan. Pendapatan asli daerah (locally raised fund) mencakup berbagai sumber seperti hasil pajak daerah, hasil retribusi daerah, hasil perusahaan milik daerah, dan hasil pengolahan kekayaan daerah lainnya yang dipisahkan, serta lain-lain pendapatan asli daerah yang sah.

Konsep manajemen keuangan daerah itu secara garis besar dapat dibagi menjadi dua bagian, yaitu manajemen penerimaan daerah dan manajemen pengeluaran daerah.Dalam rangka melaksanakan desentralisasi kedua koponen itu sangat berpengaruh (Mardiasmo,2002,104) Sementara itu secara sederhana pengertian manajemen adalah suatu kegiatan yang dilakukan untuk mencapai tujuan yang telah ditetapkan secara efektif dan efisien. Manajemen mempelajari bagaimana menciptakan efektivitas usaha (doing right thing) secara efisien (doing thing right) dan produktif, dalam rangka mencapai tujuan organisasi yang telah ditetapkan (Ndraha: 2003,159). Dalam konteks ini APBD merupakan salah satu alat atau sarana untuk mewujudkan tujuan organisasi tersebut.

\section{Faktor-faktor Yang Berperan Dalam Implementasi Kebijakan Desentralisasi Fiskal.}

Berdasarkan hasil pengamatan dan informasi dari beberapa informan diketahui bahwa masalah pendapatan daerah menyangkut aspek pelaksana dan aspek masyarakat sebagai objek penerima pelayanan sumber-sumber pendapatan serta pelaksanaan kebijakan pemungutan pajak dan retribusi daerah, membawa konsekkuensi lemahnya dukungan budgetair terhadap pelaksanaan pemerintahan dan pembangunan serta pelayanan kepada masyarakat di Provinsi Sumatera Selatan. Sebagaimana diuraikan di atas, menunjukkan bahwa persoalan pelaksanaan pemungutan sumbersumber penerimaan daerah tidak hanya menyangkut unsur pelaksanaan kebijakan dan masyarakat sebagai objek dan penggunaan pelayanan desentralisasi fiskal dari kebijakan yang dilaksanakan, tetapi bagaimana implementasi kebijakan pemungutan sumber-sumber pendapatan dapat dilakukan secara berhasil sesuai dengan tujuan utama yang diharapkan yaitu meningkatkan penerimaan daerah dari sumbersumber pendapatan daerah.

\section{Komunikasi Dalam Implementasi Kebijakan Desentralisasi Fiskal}

Implementasi kebijakan desentralisasi fiskal di Provinsi Sumatera Selatan mempunyai standar dan tujuan yang jelas. Akan tetapi menurut beberapa informan kebijakan publik bisa dilaksanakan dengan efektif,standar dan tujuan harus dipahami oleh individu (implementors) yang bertanggung jawab atas pencapaian standar dan tujuan kebijakan. Oleh karenanya standar dan tujuan harus dikomuniksikan kepada para pelaksana. Komunikasi dalam rangka penyampaian informasi kepada para pelaksana kebijakan tentang apa yang menjadi standar dan tujuan kebijakan yang konsisten dan seragam (consistency and uniformity) dari berbagai sumber informasi sangat diperlukan. Jika tidak ada kejelasan dan konsistensi serta keseragaman terhadap suatu standar dan tujuan kebijakan menurut salah satu informan, maka apa yang menjadi standar dan tujuan kebijakan tadi akan sulit untuk bisa dicapai. Dengan kejelasan itu, para pelaksana kebijakan dapat mengetahui apa yang dapat diharapkan darinya dan tahu apa yang harus mereka lakukan. Akan tetapi pada kenyataannya suatu organisasi publik, pemerintah daerah.

Faktor komunikasi menghendaki agar kebijakan publik disampaikan tidak hanya kepada pelaksana (implementors), tetapi juga kepada kelompok sasaran kebijakan dan pihak yang berkepentingan, baik langsung maupun tidak langsung terhadap kebijakan publik tadi. Karena faktor komunikasi mencakup transformasi kebijakan, kejelasan dan konsistensi. Sehingga transformasi kebijakan dapat ditransformasikan kepada para pelaksana, kelompok sasaran, dan pihak lain yang terkait dengan kebijakan implemntasi kebijakan desentralisasi fiskal di Provinsi Sumatera Selatan.

\section{Penyampaian dan Penyebaran Informasi}

Kenyataan dari temuan implementasi kebijakan desentralisasi fiskal di Provinsi Sumatera Selatan belum efektif, karena tujuan belum dipahami oleh individu-individu yang bertanggung jawab dalam pencapaian kebijakan. Ketepatan komunikasinya dengan para pelaksana, dan konsistensi atau keseragaman dari ukuran dasar dan tujuan-tujuan yang dikomunikasikan dengan berbagai sumber informasi. Akibatnya para pelaksana dapat mengetahui apa yang 
diharapkan dari ukuran-ukuran dasar dan tujuantujuan itu. Komunikasi di dalam dan antara organisasiorganisasi merupakan suatu proses yang kompleks dan sulit. Dalam meneruskan pesan-pesan ke bawah dalam suatu organisasi atau dari suatu organisasi ke organisasi lainnya, para komunikator dapat menyimpannya atau menyebarluaskannya, baik secara sengaja atau tidak sengaja. Lebih dari itu, jika sumber-sumber informasi yang berbeda memberikan interprestasiinterprestasi yang tidak konsisten terhadap ukuranukuran dasar dan tujuan-tujuan atau jika sumber-sumber yang sama memberikan interprestasi-interprestasi yang bertentangan, para pelaksana akan menghadapi kesulitan yang lebih besar untuk melaksanakan maksudmaksud kebijakan. Oleh karena itu, prospek-prospek tentang implementasi yang efektif ditentukan oleh kejelasan ukuran-ukuran dan tujuan-tujuan yang dinyatakan dengan ketepatan dan konsistensi dalam mengkomunikasikan ukuran dan tujuan tersebut :

\section{Kejelasan Informasi}

Tersumbatnya penyampaian dan penyebaran informasi, berpengaruh langsung terhadap kejelasan informasi, baik bagi pelaksana kebijakan maupun bagi masyarakat sebagai objek desentralisasi fiskal. Tidak sedikit dari kebijakan pemerintah Provinsi Sumatera Selatan yang memberikan pelayanan kepada masyarakat tidak berjalan dengan baik karena tidak jelasnya informasi, sehingga terkesan bahwa kebijakan dari pemerintah akan terputus pada tingkat pelaksanaan dari keseluruhan potensi pendapatan pendapatan daerah yang diharapkan dapat memberikan kontribusi pendapatan daerah yang relatif mudah untuk ditingkatkan. Hal tersebut menempatkan desentralisasi fiskal dalam struktur pendapatan daerah termasuk tumpuhan bagi daerah untuk dioptimalkan sumber-sumber pendapatannya.

\section{Konsistensi informasi}

Konsistensi informasi menyangkut ketepatan tindakan dari apa yang menjadi kebijakan yang telah diinformasikan dan yang harus dilaksanakan. Menurut Edwards (1980:17) bahwa “ dalam melaksanakan kebijakan, arus komunikasi yang terjadi harus jelas dan tegas, sehingga tidak dapat suatu kelonggarankelonggaran bagi para aparat pelaksana untuk menafsirkan sendiri kebijakan tersebut".

\section{Sumber Daya Dalam Implementasi Kebijakan Desentralisasi Fiskal}

Menurut informan bahwa sumber daya yang dimaksud menyangkut kecukupan pegawai baik dari kualitas maupun kuantitas, informasi yang dibutuhkan guna pengambilan keputusan, kewenangan dan fasilitas yang dibutuhkan. Dalam pelaksanaan implementasi kebijakan desentralisasi fiskal di Provinsi Sumatera Selatan, diperoleh informasi bahwa kenyataan dilapangan hasil sosialisasi dan pelatihan belum efektif dalam upaya meningkatkan peran tugas dinas pendapatan daerah di lapangan. Padahal sumber daya manusia dikembangkan secara terus menerus agar diperoleh kualitas dalam arti yang sebenarnya, yaitu pekerjaan yang dilaksanakan akan menghasilkan sesuatu yang dikehendaki. Berkualitas, bukan hanya berarti pandai saja, tetapi memenuhi semua syarat kualitatif yang dituntut pekerjaan itu benar-benar dapat diselesaikan sesuai dengan target. Syarat kualitatif yang dikehendaki itu umpamanya: adanya staf yang jelas, dana, informasi, kewenangan, dan fasilitas.

Apabila seorang pegawai akan diserahi pekerjaan yang sudah jelas standar/syarat yang dituntutnya, maka menurut informan sebaiknya dikembangkan cara pembuktiannya untuk menyatakan adanya kesesuaian antara pejabat atau pekerja dengan pegawai yang akan menduduki jabatan dan melaksanakan pekerjaan tersebut, penggunaan sumber daya tersebut dapat dijelaskan sebagai berikut:

\section{Keberadaan Staf}

Keberhasilan Implementasi kebijakan desentralisasi fiskal tidak terlepas dari sumber daya manusia atau pegawai baik secara kualitas maupun secara kuantitas dari tingkat pusat, perwakilan wilayah. Berdasarkan hasil penelitian menunjukkan adanya kelemahan-kelemahan faktor yang dimiliki oleh faktor ini sehingga implementasi desentralisasi fiskal belum sesuai dengan yang diharapkan. Dinas Pendapatan Provinsi Sumatera Selatan misalnya tidak bisa melakukan pengawasan dilapangan secara optimal disebabkan oleh kurangnya jumlah staf di lapangan, sehingga tidak memberikan suasana kondusif bagi upaya menarik minat pemilik modal melakukan investasi baik melalui penanaman modal dalam negeri (PMDN) maupun penanaman modal asing (PMA).

\section{Sumber Dana}

Sumber daya penting lainnya adalah ketersediaan dana yang diperlukan untuk membiayai operasionalisasi kebijakan. Menurut Peraturan Pemerintah (PP) Nomor 104 tahun 2000, ada tiga sumber dana perimbangan yaitu (1) Bagi hasil pajak dan penerimaan sumber daya alam (SDA). (2) Dana Alokasi Umum (DAU). (3) Dana Alokasi Khusus (DAK). Ketiga, alokasi dana melalui DAK biasanya memerlukan kontribusi dana dari daerah yang bersangkutan, semacam matching grant. Oleh karena itu kebijakan mengenai alokasi dana DAK perlu lebih disempurnakan dan difokuskan kepada pembiayaan pelayanan dasar yang memberikan manfaat spillover effect seperti pengurangan kemiskinan.

Anggaran dapat digunakan sebagai alat untuk memotivasi gubernur dan stafnya agar bekerja secara ekonomis, efektif, dan efisien dalam mencapai target 
serta tujuan organisasi yang telah ditetapkan. Agar dapat memotivasi pegawai, anggaran hendaknya bersifat challenging but attainable atau demanding but achieveable. Maksudnya adalah target anggaran hendaknya jangan terlalu tinggi sehingga tidak dapat dipenuhi. Namun juga jangan terlalu rendah sehingga terlalu mudah untuk dicapai.

\section{Informasi}

Sumber informasi menyangkut ketersediaan keterangan-keterangan atau data yang dimiliki dalam mengimplementasikan suatu kebijakan, terutama menyangkut data-data yang berhubungan desentralisasi fiskal di Provinsi Sumatera Selatan. Dinas Pendapatan Daerah dan Biro keuangan Pemda Provinsi Sumatera Selatan memiliki informasi yang akurat tentang sistem informasi keuangan daerah secara nasional. Hal ini terlihat tingginya kualitas informasi itu sangat penting karena informasi adalah basis kejujuran dan proses pengambilan keputusan yang baik. Hal ini terjadi karena pelaporan yang teratur tentang biaya, output dan dampak suatu kebijakan adalah sangat penting. Begitu juga informasi yang kredibel dan reliable akan menjamin tingginya kualitas akuntabilitas publik.

\section{Kewenangan}

Realisasi penerimaan Pendapatan Asli Daerah, erat kaitannya dengan Kewenangan atau authority yang dimiliki oleh daerah dalam mengelolapenerimaan daerah dan merupakan dasar untuk bertindak, berbuat dan melakukan kegiatan/ aktivitas tertentu ( Hasibuan, 2001 : 66 ) Pada prinsipnya pelaksanaan program perlu disertai dengan pemberian kewenangan yang jelas, sehingga aparat pelaksana di lapangan akan secara tegas bertindak dan melakukan tugas yang diembannya. Sebaliknya, kewenangan yang telah diberikan kebebasan untuk menentukan ruang lingkup pajak, retribusi maupun penerimaan lainnya, serta metode penilaian dan tarif pajak sendiri harus dipertanggungjawabkan kepada yang memberi tanggung jawab. Menurut Davey, jelas akan mendorong kebebasan dan fleksibelitas dalam pembiayaan kegiatan pemerintah regional. Sedangkan Collions (1992:12) menyatakan bahwa: "Pusat dapat mendorong pemerintah daerah untuk meningkatkan lebih banyak pendapatan pajak (tax revenue) melalui pajak-pajak baru, retribusi-retribusi atau pinjaman. Jika Pemerintah Pusat berperan dalam meningkatkan penerimaan. Maka unconditional grant tampaknya merupakan instrumen yang paling tepat. Kewenangan untuk menggali dan memungut pendapatan daerah, sangat erat dengan pengaturan hubungan keuangan antara pemerintah Pusat dengan Daerah".

\section{Fasilitas}

Fasilitas merupakan faktor penting yang akan menunjukkan pelaksanaan suatu program kebijakan desentralisasi fiskal. Salah satu kendala dalam meng- gali sumber-sumber pendapatan daerah di lapangan adalah masih minimnya sarana dan prasarana yang tersedia untuk menunjang kebijakan tersebut. Masih jauhnya pelabuhan laut dari lokasi pertambangan sehingga kurangnya investor untuk menambang di Provinsi Sumatera Selatan.

\section{Disposisi atau Sikap Pelaksana Dalam Implemen- tasi Kebijakan Fiskal}

Disposisi atau sikap pelaksana dalam implementasi kebijakan diartikan sebagai, kecenderungan, keinginan atau kesepakatan para pelaksana untuk melaksanakan kebijakan. Sikap ini juga menyangkut kesadaran pelaksana pada setiap tingkatan tugas/ pekerjaan yang menjadi tanggung jawab dan akan membawa dampak yang sangat positif ataupun sebaliknya terhadap organisasi dan tugas/ pekerjaan itu sendiri, sesuai dengan standar yang telah ditetapkan.

\section{Struktur Birokrasi Dalam Implementasi Kebijakan Desentraliasasi Fiskal}

Struktur birokrasi mempunyai peran yang penting dalam keberhasilan implementasi kebijakan suatu kebijakan. Implementasi kebijakan desentralisasi fiskal di Provinsi Sumatera Selatan yang bertujuan untuk meningkatkan penerimaan daerah serta memberikan pelayanan kepada masyarakat.

Menurut Edward (1980:125) mengatakan bahwa "meskipun sumber-sumber untuk mengimplementasikan suatu kebijakan cukup dan para pelaksana (implementors) mengetahui apa dan bagaimana cara melakukannya, implementasi kebijakan bisa jadi belum efektif, karena adanya ketidak efisienan struktur birokrasi.

\section{SIMPULAN}

Implementasi kebijakan desentralisasi fiskal di Provinsi Sumatera Selatan menunjukkan beberapa kendala antara lain, pada dasarnya belum optimalnya Provinsi Sumatera Selatan dalam mengatasi kekurangan pendapatan, mengatasi eksternalitas dan melakukan redistribusi pendapatan nasional, serta menstabilkan ekonomi makro di Sumatera Selatan demi tercapainya penguatan dan stabilitas ekonomi secara nasional. Dan beberapa kendala antara lain, faktor komunikasi yang menunjukkan bahwa jalinan komunikasi yang terbangun dalam pengelolaan keuangan daerah, di antara para implementor menunjukkan masih kurang. Tingkat penerimaan dan pemahaman di antara petugas pengelolaan keuangan daerah terkesan belum memiliki kesamaan persepsi sehingga menyebabkan rendahnya penyebaran akses informasi desentralisasi fiskal kepada Pemerintah Daerah. Faktor sumber daya tenaga pengelolaan keuangan yang belum berperan signifikan terhadap implementasi kebijakan desentralisasi fiskal khususnya Dinas Pendapatan Daerah Provinsi Sumatera Selatan. yang belum transparan dalam upaya meningkatkan pendapatan daerah menyebabkan tingkat ketergantungan yang cukup bersar terhadap Pemerintah Pusat. Sebagian besar terlihat adanya' tarik ulur' kewenangan antara pusat dan daerah; pola sentralisasi 
fiskal menumbuhkan ketergantungan yang kuat sehingga 'kreativitas' daerah untuk mengoptimalkan penerimaan sendiri relatif rendah; Faktor kecenderungan perilaku tenaga Dispenda memberikan kesan dalam periode pengamatan kurang memacu pertumbuhan daerah; Selain itu, struktur birokrasi yang belum memperhatikan adanya jalinan kerjasama dan koordinasi dalam implementasi kebijakan desentralisasi fiskal di Provinsi Sumatera Selatan.

Berdasarkan kesimpulan tersebut diatas, maka di rekomendasikan yang dapat diangkat dari hasil temuan penelitian yaitu keberhasilan implementasi kebijakan desentralisasi fiskal dapat dicapai melalui peningkatan kemampuan Anggaran Daerah, pemahaman dan sikap konsisten para pelaku pelaksana kebijakan, komitmen dan tanggungjawab dari pemerintah daerah selaku organizational level. Sedangkan untuk mengalokasikan semua anggaran, penetapan kejelasan kewenangan, kejelasan metode dan prosedur kerja, dan kejelasan standar yang dijadikan sebagai pedoman dalam implementasi kebijakan desentralisasi fiskal serta dapat memperkuat teori kebijakan publik yang ada, khususnya teori implementasi kebijakan publik dari George Edwards III.

\section{DAFTAR PUSTAKA}

Abidin, Said Zainal. 2004. Kebijakan Public. Jakarta: Yayasan Pancur Siwah.

Bird, Richard M \& Francois Vaillancourt (ed), (penerjemah Almizan Ulfa), 2000. Desentralisasi Fiskal di Negara-negara Berkembang, Jakarta: PT Gramedia Pustaka Utama.

Bogdan, Robert C. and Steven J. Taylor. 1992. Introductions to Qualitative Research Methods: A Phenomenological Approach in the Social Science. Ahli Bahasa Arief Furchan, John Wiley and Sons. Surabaya: Usaha Nasional.

Collions, John and Jones, Phillip. 1992. Public Finance and Public Choice: Analitical Perspective. Singapura. MC Graw-Hill International Edition.

Creswell, John. W. 1994. Research Design Qualitative and Quantitative Approaches. UK- New DelhiCalifornia: Sage Publication.

Davey, K.J. 1988, Pembiayaan Pemerintahan Daerah: Praktek-Praktek Internasional dan Relevansinya bagi Dunia Ketiga Amanullah, Hamdani Amin, A.T Pakpahan, Busroni, Bachrul Elmi; Pendamping Santoro Isman (Penerjemah), Penerbit Universitas Indonesia Indonesia Jakarta: (UI- Press)

Devas, Nick, et.al, 1989 ( penerjemah Masri Maris ). Keuangan Pemerintah Daerah di Indonesia. Jakarta: Penerbit UI Press.

Dye, Thomas R, 1997. Understanding Public policy, Englewood Cliffts, N.J. Prentice Hall, Inc.
Edwards III, GeorgeC. 1980. Implementing Public Policy. United States of America Congressional Quarterly Inc.

Fleet, David D. Van.1988. Contemporary Management, Boston: Houghton Mifflin Company.

Hasibuan, Malayu S. P. 2001. Organisasi dan Motivasi: Dasar Peningkatan Produktivitas. Jakarta : Bumi Aksara.

Hungtington, Samuel P. dan Joan Nelson. 1990. Partisipasi Politik di Negara Berkembang Terjemahan Sahat Simamora. Jakarta: Penerbit PT. Rineka Cipta.

Hyman, David N. 1999. Public Finance, A Contemporary Application of Theory to Policy, 6 th.ed., USA: The Dryden Press, Fortworth, Tx.

Kaho, Josef Riwu. 2001. Prospek Otonomi Daerah di Negara Republik Indonesia, Jakarta: PT Raja Grafindo Persada.

Koswara, Ekom, 1997, Otonomi Daerah untuk Demokrasi dan Kemandirian Rakyat, Jakarta: Yayasan Pariba.

Kuncoro Mudrajad 1995, Desentralisasi fiskal Di Indonesia- Delema Otonomi dan Ketergantungan Prima No.4 Tahun XXIV.

Mardiasmo, 2002, Keuangan Publik dalam Pelaksanaan Otonomi Daerah, Yogyakarta ,Yogyakarta: Penerbit Andi.

Maxwell, Joseph A. 1996. Qualitative Research Design, an Integrative Approach. California: Sage Publications, Inc.

Moleong, Lexi J, 1997, Metodologi Penelitian Kualitatif, Bandung: CV Remaja Rosda Karya.

Nazara, Suahasil, 1997.,Kebijakan Pemerintah Daerah dalam meningkatkan PAD.,Prisma( ed.3 ).

Ndraha Taliziduhu, 1997, Metodologi Ilmu Pemerintahan. Jakarta : Rineka Cipta.

Ndraha Taliziduhu, 2003. Kybernologi ( Ilmu Pemerintahan baru ) Jakarta: Rineka Cipta.

Riduwan. 2002. Skala Pengukuran Variabel-Variabel Penelitian. Bandung: Penerbit Alfabeta.

Samugyo Ibnu Redjo. 1998. Keuangan Pusat dan Daerah. Bandung BKU Ilmu Pemerintahan.

Strauss, A dan Corbin, J. 1990. Basic Qualitatif Research: Grounded Theory Procedures and Technique. Newbury Park: Sage Publication.

Shah, Anwar, 1994, Intergoverment Fiscal Relations in Indonesia, Discussion Paper No. 239, Washington D.C., World Bank.

Undang - Undang Dasar 1945 Undang-Undang Nomor 34 Tahun 2000 Tentang Perubahan Atas Undang-Undang Nomor 18 Tahun 1997 Tentang Pajak Daerah dan Retribusi Daerah. 
Undang-Undang Nomor 22 Tahun 1999 Tentang Pemerintahan Daerah.

Undang-Undang Nomor 25 Tahun 1999 Tentang Perimbangan Keuangan antara Pemerintah Pusat dan Daerah.

Undang-Undang Nomor 32 Tahun 2004, Tentang Pemerintahan Daerah.

Undang-Undang Nomor 33 Tahun 2004, Tentang Perimbangan Keuangan antara Pemerintah Pusat dan Daerah.
Peraturan Pemerintah Nomor 104 Tahun 2000, Tentang Dana Perimbangan.

Peraturan Pemerintah Nomor 105 Tahun 2000, Tentang Pengelolaan dan Pertanggung jawaban Keuangan Daerah.

Peraturan Pemerintah Nomor 55 Tahun 2005 Tentang Dana Perimbangan. 